\title{
KONSEP PERENCANAAN PEMBANGUNAN PARTISIFATIF DI DAERAH
}

\author{
Rusman Sitonda, Rais Rahmat Razak, Lahibu Tuwu \\ Magister Administrasi Publik STISIP Muhammadiyah Rappang \\ Sidenreng Rappang, Indonesia \\ rusmansitonda@gmail.com,mraisrahmat@yahoo.com, lahibutuwu@yahoo.co.id
}

\begin{abstract}
ABSTRAK - Sistem perencanaan partisifatif tercipta apabila perencanaan tersebut sepenuhnya mencerminkan kebutuhan konkrik masyarakat yang dalam proses penyusunannya benar-banar melibatkan masyarakat. Hubungan antara partisipasi masyarakat dengan proses perencanaan pembangunan pada klasifikasi berpengaruh, namun hal ini tidak terlepas dari faktor-faktor yang mempengaruhi partisipasi masyarakat dalam perencanaan yaitu (I) Faktor kemauan yang ditandai dengan adanya motif seseorang untuk berpartisipasi dalam proses perencanaan. (2) Faktor Kesempatan yang ditandai dengan tersedianya waktu untuk ikut berpartisipasi dalam proses perencanaan (3) dan faktor kemampuan yang ditandai oleh kemampuan baca tulis dan tingkat pengetahuan masyarakat. Kondisi ini pada umumnya di Desa dan Kelurahan memiliki kompetensi dan ketrampilan yang berkaitan dengan tahapantahapan Musrenbang.
\end{abstract}

Kata Kunci - Partisipasi Masyarakat, Proses Perencanaan, Pembangunan.

\section{PENDAHULUAN}

Perencanaan adalah proses menyusun langkahlangkah yang akan diselenggarakan oleh pemerintah daerah dalam rangka menjawab kebutuhan masyarakat, guna mencapai suatu tujuan tertentu. Perencanaan daerah dapat dipandang sebagai suatu formulasi atau rumusan mengenai aspirasi masyarakat setempat, dalam rangka mencapai suatu kehidupan baru yang lebih baik dan bermakna melalui langkah-langkah pembangunan.

Secara umum kita mengenal dua model perencanaan yaitu : (I). Perencanaan yang ditentukan langsung dari pusat atau pemerintah yang lebih tinggi (top-down), sehingga pemerintah daerah hanya merupakan pelaksana atau pelengkap dari konsep yang sudah ada; dan (2). Perencanaan partisipatif (button-up) yang merupakan hasil dari pergulatan masyarakat setempat dengan menggunakan mekanisme formal dan nonformal (bersifat partisifatif). Kualitas dari perencanaan daerah dan implikasinya pada kehidupan masyarakat sangat ditentukan oleh model yang dipilih.

Suatu perencanaan disebut partisifatif apabila perencanaan tersebut sepenuhnya mencerminkan kebutuhan konkrik dalam proses penyusunannya benar-benar melibatkan masayarakat. Perlu disadari, bahwa ada beberapa kendala yang muncul apabila perencanaan harus melibatkan massa rakyat. Pertama, kenyataan bahwa massa rakyat umumnya adalah pihak yang tidak memiliki kesempatan menikmati pendidikan formal yang memadai. Karena rendahnya kemampuan baca tulis dan keterbatasan pengetahuan, massa rakyat sulit bisa ambil bagian secara produktif dalam proses prencanaan pembangunan daerah. Kedua, Massa rakyat telah ditradisikan dalam proses politik yang mengekor, pasif, takut mengambil inisiatif dan hidup dalam budaya petunjuk oleh yang dituakan atau ditokohkan dalam suatu kelompok masyarakat. Akibatnya, ketika ada kebutuhan untuk mendorong adanya prakarsa masyarakat dalam perencanaan pembangunan hal ini tidak sertamerta bisa dilakukan.

Perencanaan daerah yang berbasis prakarsa rakyat (partisipatif) pada dasarnya membutuhkan dua syarat utama, yaitu : (I). Perlu adanya suatu langkah dalam rangka proses policy reform, yakni adanya perubahan kebijakan menyangkut 
perubahan atas kebijakan-kebijakan yang membentengi, membatasi dan tidak memberikan pengakuan pada aspirasi rakyat. Artinya, perencanaan hanya bisa dijalankan bila sejumlah proses awal dilakukan seperti pengembangan pendidikan politik dan upaya-upaya untuk memperluas ruang politik rakyat. (2). Perencanaan dalam konteks ini dapat dipandang dan ditempatkan sebagai bagian dari proses pendidikan politik yakni proses yang memungkinkan rakyat untuk merumuskan kebutuhannya, menyadari keterlibatan politiknya, dan menentuakan apa yang hendak dirumuskan oleh penguasa.

Lahirnya Undang-Undang No. 25 Tahun 2004 tentang Sistem Perencanaan Pembangunan Nasional (SPPN) dan Undang-Undang No. 17 Tahun 2003 memberikan pengaruh yang cukup mendasar terhadap pelaksanaan proses perencanaan di daerah. Hal -hal yang sangat prinsip antara lain adalah : (I). Mekanisme atau hirearki perencanaan pembangunan nasional di daerah yakni dengan diberlakukannya Rencana Pembangunan Jangka Panjang (RPJP) yang berlaku selama 20 tahun. Adanya Rencana Pembangunan Jangka Menegah (RPJM) yang berlaku selam 5 tahun yang merupakan penjabaran visi dan misi kepala daerah dan adanya Rencana Kerja Pemerintah Daerah (RKPD) yang berlaku tiap satu tahun yang merupakan turunan dari RKPD. (2). Mekanisme penganggaran daerah menghasilkan produk APBD sebagai bentuk operasional dari perencanaan pembangunan di atur dengan undang-undang yang berbeda, yaitu UU No. 17 tahun 2003 tentang Keuangan Negara (3). Dengan pengaturan yang berbeda antara sistem perencanaan pembangunan dengan proses penganggaran mengakibatkan sering terjadi terputusnya proses perencanaan pembangunan dengan proses penganggaran, meskipun dalam UU No. 17 tahun 2003 pasal 18 disebutkan, bahwa arah kebijakan pembangunan harus selajan dengan rencana kerja pemerinta daerah (RKPD) yang telah ditetapkan. (4). Implikasi-implikasi yang timbul karena perbedaan persepsi tentang perundangan dalam proses perencanaan pada akhirnya mengakibatkan keberagaman model mekanisme perencanaan pembangunan di berbagai daerah.

Pada sisi lain, berkembangnya konsep pemberdayaan memerlukan tumbuhnya sikap dan wawasan yang mendasar, jernih serta kuat mengenai kekuasaan (power). Sebagai suatau alternatif pembangunan, paradigma pemberdayaan pada intinya memberikan tekanan pada otonomi pengambilan keputusan dari suatu kelompok masyarakat yang berlandaskan pada sumber daya pribadi, alngsung melalui partisispasi, demokrasi, dan pembelajaran sosial melalui pengalaman langsung.

Pengertian prinsip partisipasi adalah masyarakat berperan secara aktif dalam proses atau alur tahapan program dan pengawasannya, mulai dari tahap sosialisasi, perencanaan, pelaksanaan, dan pelestarian kegiatan dengan memberikan sumbangan tenaga, pikiran, atau dalam bentuk materill (PTO PNPM PPK, 2007). Selvia (2010: 77) menyatakan bahwa patisipasi adalah the taking part in one ore more phases of the process. Sedangkan Keith Davis (1967) menyatakan bahwa patisipasi "as mental and emotional involment of persons of person in a group situation which encourages him to contribute to group goals and share responsibility in them"

Verhangen (1979) dalam Mardikanto (2003: 34) menyatakan bahwa, partisipasi merupakan suatu bentuk khusus dari interaksi dan komunikasi yang berkaitan dengan pembagian: kewenangan, tanggung jawab, dan manfaat. Theodorson dalam Mardikanto (2003) mengemukakan bahwa dalam pengertian seharihari, partisipasi merupakan keikutsertaan atau keterlibatan seseorang (individu atau warga masyarakat) dalam suatu kegiatan tertentu. Keikutsertaan atau keterlibatan yang dimaksud di sini bukanlah bersifat pasif tetapi secara aktif ditujukan oleh yang bersangkutan.

Oleh karena itu, partisipasi akan lebih tepat diartikan sebagi keikutsertaan seseorang didalam suatu kelompok sosial untuk mengambil bagian dalam kegiatan masyarakatnya, di luar pekerjaan atau profesinya sendiri. Faktor-faktor yang mempengaruhi terhadap tumbuh dan berkembangnya partisipasi dapat didekati dengan 
beragam pendekatan disiplin keilmuan. Menurut konsep proses pendidikan, partisipasi merupakan bentuk tanggapan atau responses atas rangsanganrangsangan yang diberikan; yang dalam hal ini, tanggapan merupakan fungsi dari manfaat (rewards) yang dapat diharapkan (Kunaryo, 2004: 44).

Partisipasi masyarakat menurut Ratan Waluyo (200I: 20) adalah proses ketika warga sebagai individu maupun kelompok sosial dan organisasi, mengambil peran serta ikut mempengaruhi proses perencanaan, pelaksanaan, dan pemantauan kebijakan kebijakan yang langsung mempengaruhi kehidupan mereka. Conyers (200I: 5I) menyebutkan tiga alasan mengapa partisipasi masyarakat mempunyai sifat sangat penting, yaitu: (I) partisipasi masyarakat merupakan suatu alat guna memperoleh informasi mengenai kondisi, kebutuhan, dan sikap masyarakata, tanpa kehadirannya program pembangunan serta proyek-proyek akan gagal; (2) masyarakat akan lebih mempercayai proyek atau program pembangunan jika merasa dilibatkan dalam proses persiapan dan perencanaannya, karena mereka akan mengetahui seluk beluk proyek tersebut dan akan mempunyai rasa memiliki terhadap poyek tersebut; dan (3) yang mendorong adanya partisiapsi umum di banyak negara karena timbul anggapan bahwa merupakan suatu hak demokrasi bila masyarakat dilibatkan dalam pembangunan masyarakat mereka sendiri.

Penumbuhan dan pengembangan partisipasi masyarakat seringkali terhambat oleh persepsi yang kurang tepat, yang menilai masyarakat sulit diajak maju oleh sebab itu kesulitan penumbuhan dan pengembangan partisipasi masyarakat juga disebabkan karena sudah adanya campur tangan dari pihak penguasa. Berikut adalah macam tipologi partisipasi masyarakat:

I. Partisipasi Pasif/manipulatif dengan karakteristik masyarakat diberitahu apa yang sedang atau telah terjadi, pengumuman sepihak oleh pelaksanaan proyek yang memperhatikan tanggapan masyarakat dan informasi yang diperlukan terbatas pada kalangan profesional di luar kelompok sasaran;

2. Partisipasi Informatif memilki karakteristik dimana masyarakat menjawab pertanyaan- pertanyaan penelitian, masyarakat tidak diberikesempatan untuk terlibat dan mempengaruhi proses penelitian dan akurasi hasil penelitian tidak dibahas bersama masyarakat;

3. Partisipasi konsultatif dengan karateristik masyarakat berpartisipasi dengan cara berkonsultasi, tidak ada peluang pembuatan keputusan bersama, dan para profesional tidak berkewajiban untuk mengajukan pandangan masyarakat (sebagi masukan) atau tindak lanjut;

4. Partisipasi intensif memiliki karakteristik masyarakat memberikan korbanan atau jasanya untuk memperoleh imbalan berupa intensif/upah. Masyarakat tidak dilibatkan dalam proses pembelajan atau eksperimeneksperimen yang dilakukan dan asyarakat tidak memiliki andil untuk melanjutkan kegiatan-kegiatan setelah intensif dihentikan;

5. Partisipasi Fungsional memiliki karakteristik masyarakat membentuk kelompok untuk mencapai tujuan proyek, pembentukan kelompok biasanya setelah ada keptusankeputusan utama yang di sepakati, pada tahap awal masyarakat tergantung terhadap pihak luar namun secara bertahap menunjukkan kemandiriannya;

6. Partisipasi interaktif memiliki ciri dimana masyarakat berperan dalam analisis untuk perencanaan kegiatan dan pembentukan penguatan kelembagaan dan cenderung melibatkan metoda interdisipliner yang mencari keragaman prespektik dalam proses belajar mengajar yang terstuktur dan sisteatis. Masyarakat memiliki peran untuk mengontrol atas (pelaksanaan) keputusan-keputusan merek, sehingga memiliki andil dalam keseluruhan proses kegitan;

7. Self mobilization (mandiri) memiliki karakter masyarakat mengambil inisiatif sendiri secara bebas (tidak dipengaruhi oleh pihak luar) untuk mengubah sistem atau nilai-nilai yang mereka miliki.

Adapun tahapan dalam melakukan partisipasi dapat diuraikan dari masing-masing tahapan partisipasi adalah sebagai berikut : 
I. Tahap partisipasi dalam pengambilan keputusan, Pada umumnya, setiap program pembangunan masyarakat (termasuk pemanfaatan sumber daya lokal dan alokasi anggarannya) selalu ditetapkan sendiri oleh pemerintah pusat, yang dalam hal ini lebih mencerminkan sifat kebutuhan kelompokkelompok elit yang berkuasa dan kurang mencerminkan keinginan dan kebutuhan masyarakat banyak. Karena itu, partisipasi masyarakat dalam pembangunan perlu ditumbuhkan melalui dibukanya forum yang memungkinkan masyarakat banyak berpartisipasi langsung di dalam proses pengambilan keputusan tentang programprogram pembangunan di wilayah setempat atau di tingkat lokal (Mardikanto, 2003: 60).

2. Tahap partisipasi dalam perencanaan kegiatan Rizal (200I: 34) membedakan ada tingkatan partisipasi yaitu : partisipasi dalam tahap perencanaan, partisipasi dalam tahap pelaksanaan, partisipasi dalam tahap pemanfaatan. Partisipasi dalam tahap perencanaan merupakan tahapan yang paling tinggi tingkatannya diukur dari derajat keterlibatannya. Dalam tahap perencanaan, orang sekaligus diajak turut membuat keputusan yang mencakup merumuskan tujuan, maksud dan target. Salah satu metodologi perencanaan pembangunan yang baru adalah mengakui adanya kemampuan yang berbeda dari setiap kelompok masyarakat dalam mengontrol dan ketergantungan mereka terhadap sumbersumber yang dapat diraih di dalam sistem lingkungannya. Pengetahuan para perencana teknis yang berasal dari atas umumnya amat mendalam. Oleh karena keadaan ini, peranan masyarakat sendirilah akhirnya yang mau membuat pilihan akhir sebab mereka yang akan menanggung kehidupan mereka. Oleh sebab itu, sistem perencanaan harus didesain sesuai dengan respon masyarakat, bukan hanya karena keterlibatan mereka yang begitu esensial dalam meraih komitmen, tetapi karena masyarakatlah yang mempunyai informasi yang relevan yang tidak dapat dijangkau perencanaan teknis atasan (Widodo, 2006: 19).

3. Tahap partisipasi dalam pelaksanaan kegiatan Partisipasi masyarakat dalam pembangunan, seringkali diartikan sebagai partisipasi masyarakat banyak (yang umumnya lebih miskin) untuk secara sukarela menyumbangkan tenaganya di dalam kegiatan pembangunan. Di lain pihak, lapisan yang ada di atasnya (yang umumnya terdiri atas orang kaya) yang lebih banyak memperoleh manfaat dari hasil pembangunan, tidak dituntut sumbangannya secara proposional. Karena itu, partisipasi masyarakat dalam tahap pelaksanaan pembangunan harus diartikan sebagai pemerataan sumbangan masyarakat dalam bentuk tenaga kerja, uang tunai, dan atau beragam bentuk korbanan lainnya yang sepadan dengan manfaat yang akan diterima oleh warga yang bersangkutan (Mardikanto, 2003: 69).

4. Tahap partisipasi dalam pemantauan dan evaluasi kegiatan Kegiatan pemantauan dan evaluasi program dan proyek pembangunan sangat diperlukan. Bukan saja agar tujuannya dapat dicapai seperti yang diharapkan, tetapi juga diperlukan untuk memperoleh umpan balik tentang masalah-masalah dan kendala yang muncul dalam pelaksanaan pembangunan yang bersangkutan. Dalam hal ini, partisipasi masyarakat mengumpulkan informasi yang berkaitan dengan perkembangan kegiatan serta perilaku aparat pembangunan sangat diperlukan (Mardikanto, 2003: 80).

5. Tahap partisipasi dalam pemanfaatan hasil kegiatan Partisipasi dalam pemanfaatan hasil pembangunan, merupakan unsur terpenting yang sering terlupakan. Sebab tujuan pembangunan adalah untuk memperbaiki mutu hidup masyarakat banyak sehingga pemerataan hasil pembangunan merupakan tujuan utama. Di samping itu, pemanfaaatan hasil pembangunan akan merangsang kemauan dan kesukarelaan masyarakat untuk selalu berpartisipasi dalam setiap program pembangunan yang akan datang (Mardikanto, 2003: 85). 
Endarlin (2003: 44) membedakan adanya beberapa jenjang kesukarelaan sebagai berikut: (I). Partisipasi spontan, yaitu peran serta yang tumbuh karena motivasi intrinsik berupa pemahaman, penghayatan, dan keyakinannya sendiri.; (2). Partisipasi terinduksi, yaitu peran serta yang tumbuh karena terinduksi oleh adanya motivasi ekstrinsik (berupa bujukan, pengaruh, dorongan) dari luar; meskipun yang bersangkutan tetap memiliki kebebasan penuh untuk berpartisipasi; (3). Partisipasi tertekan oleh kebiasaan, yaitu peran serta yang tumbuh karena adanya tekanan yang dirasakan sebagaimana layaknya warga masyarakat pada umumnya, atau peran serta yang dilakukan untuk mematuhi kebiasaan, nilai-nilai, atau norma yang dianut oleh masyarakat setempat. Jika tidak akan tersisih atau dikucilkan masyarakatnya; (4). Partisipasi tertekan oleh alasan sosialekonomi, yaitu peran serta yang dilakukan karena takut akan kehilangan status sosial atau menderita kerugian/tidak memperoleh bagian manfaat dari kegiatan yang dilaksanakan; (5). Partisipasi tertekan oleh peraturan, yaitu peran serta yang dilakukan karena takut menerima hukuman dari peraturan/ketentuan-ketentuan yang sudah diberlakukan.

Isbandi Rahminto (2007:77) menyatakan bahwa tumbuh dan berkembangnya partisipasi masyarakat dalam pembangunan, sangat ditentukan oleh 3 (tiga) unsur pokok, yaitu: (I). Adanya kemauan yang diberikan kepada masyarakat untuk berpartisipasi; (2). Adanya kesempatan masyarakat untuk berpartisipasi; (3). Adanya kemampuan masyarakat untuk berpartisipasi.

Lebih rinci Slamet menjelaskan tiga persyaratan yang menyangkut kemauan, kemampuan dan kesempatan untuk berpartisipasi adalah sebagai berikut: Pertama Kemauan. Secara psikologis kemauan berpartisipasi muncul oleh adanya motif intrinsik (dari dalam sendiri) maupun ekstrinsik (karena rangsangan, dorongan atau tekanan dari pihak luar). Tumbuh dan berkembangnya kemauan berpartisipasi sedikitnya diperlukan sikap-sikap yang: (a) Sikap untuk meninggalkan nilai-nilai yang menghambat pembangunan; (b) Sikap terhadap penguasa atau pelaksana pembangunan pada umumnya; (c) Sikap untuk selalu ingin memperbaiki mutu hidup dan tidak cepat puas sendiri; (d) Sikap kebersamaan untuk dapat memecahkan masalah, dan tercapainya tujuan pembangunan; (e) Sikap kemandirian atau percaya diri atas kemampuannya untuk memperbaiki mutu hidupnya.

Kedua,. Kemampuan. Beberapa kemampuan yang dituntut untuk dapat berpartisipasi dengan baik itu antara lain adalah: (a) Kemampuan untuk mengidentifikasi masalah; (b) Kemampuan untuk memahami kesempatan-kesempatan yang dapat dilakukan untuk memecahkan masalah yang dihadapi dengan memanfaatkan sumberdaya yang tersedia; (c) Kemampuan untuk melaksanakan pembangunan sesuai dengan pengetahuan dan keterampilan serta sumber daya lain yang dimiliki. Grindel (2005: 90) kemampuan adalah kapasitas individu melaksanakan berbagai tugas dalam suatu pekerjaan., pada hakikatnya kemampuan individu tersuusun dari dua perangkat faktor yaitu kemampuan intelektual dan kemampuan fisik.

Ketiga, Kesempatan. Berbagai kesempatan untuk berpartisipasi ini sangat dipengaruhi oleh: (a) Kemauan politik dari penguasa/pemerintah untuk melibatkan masyarakat dalam pembangunan; (b) Kesempatan untuk memperoleh informasi; (c) Kesempatan untuk memobilisasi dan memanfaatkan sumberdaya; (d) Kesempatan untuk memperoleh dan menggunakan teknologi tepat guna; (e) Kesempatan untuk berorganisasi, termasuk untuk memperoleh dan mempergunakan peraturan, perizinan dan prosedur kegiatan yang harus dilaksanakan; (f) Kesempatan untuk mengembangkan kepemimpinan yang mampu menumbuhkan, menggerakkan dan mengembangkan serta memelihara partisipasi masyarakat dalam pembangunan.

Mardikanto (2003: 100) menjelaskan adanya kesempatan yang diberikan, sering merupakan faktor pendorong tumbuhnya kemauan, dan kemauan akan sangat menentukan kemampuannya. Kemauan untuk berpartisipasi 
merupakan kunci utama bagi tumbuh dan berkembangnya partisipasi masyarakat. Sebab, kesempatan dan kemampuan yang cukup, belum merupakan jaminan bagi tumbuh dan berkembangnya partisipasi masyarakat, jika mereka sendiri tidak memiliki kemauan untuk (turut) membangun. Sebaliknya, adanya kemauan akan mendorong seseorang untuk meningkatkan kemam-puan dan aktif memburu serta memanfaatkan setiap kesempatan. (Carl Bellene, 2000: 57).Mardikanto (2003:III) menjelaskan beberapa kesempatan yang dimaksud adalah kemauan politik dari penguasa untuk melibatkan masyarakat dalam pembagunan, baik dalam pengambilan kepu-tusan perencanaan, pelaksanaan, monitoring dan evaluasi, pemeliharaan, dan pemanfaatan pembangunan; sejak di tingkat pusat sampai di jajaran birokrasi yang paling bawah. Selain hal tersebut terdapat kesempatankesempatan yang lain diantaranya kesempatan untuk memperoleh informasi pembangunan, kesempatan memanfaatkan dan memobilisasi sumber daya (alam dan manusia) untuk pelaksanaan pembangunan.

Kesempatan untuk memperoleh dan menggunakan teknologi yang tepat (termasuk peralatan perlengkapan penunjangnya). Kesempatan untuk berorganisasi, termasuk untuk memperoleh dan menggunakan peraturan, perijinan, dan prosedur kegiatan yang harus dilaksanakan, dan Kesempatan mengembangkan kepemimpinan yang mampu menumbuhkan, menggerakkan, dan mengembangkan serta memelihara partisipasi masyarakat (Usman Hamaru, 2008: 65).

Adanya kesempatan-kesempatan yang disediakan untuk menggerakkkan partisipasi masyarakat akan tidak banyak berarti, jika masyarakatnya tidak memiliki kemampuan untuk berpartisipasi. Usman Hamaru (2008:74) menjelaskan yang dimaksud dengan kemampuan di sini adalah; (I). Kemampuan untuk menemukan dan memahami kesempatankesempatan untuk membangun, atau pengetahuan tentang peluang untuk membangun (memperbaiki mutu hidupnya); (2). Kemampuan untuk melaksanakan pembangunan, yang dipengaruhi oleh tingkat pendidikan dan keterampilan yang dimiliki; (3) Kemampuan untuk memecahkan masalah yang dihadapi dengan menggunakan sumberdaya dan kesempatan (peluang) lain yang tersedia secara optimal.

Yadav dalam Mardikanto (2003: 77) mengemukakan adanya empat macam kegiatan yang menunjukkan partisipasi masyarakat dalam pembangunan yaitu : partisipasi dalam pengambilan keputusan, partisipasi dalam pelaksanaan kegiatan, partisipasi dalam pemantauan dan evaluasi, dan partisipasi dalam pemanfaatan hasil pembangunan. Tumbuh dan berkembangnya partisipasi masyarakat dalam proses pembangunan, menunjukkan adanya kepercayaan dan kesempatan yang diberikan "pemerintah" kepada masyarakatnya untuk terlibat secara aktif di dalam proses pembangunan.

Tumbuh dan berkembangnya partisipasi masyarakat, memberikan indikasi adanya pengakuan (aparat) pemerintah bahwa masyarakat bukanlah sekedar obyek atau penikmat hasil pembangunan, melainkan subyek atau pelaku pembangunan yang memiliki kemauan dan kemampuan yang dapat diandalkan sejak perencanaan, pelaksanaan, pengawasan, dan pemanfaatan hasil-hasil pembangunan (Stoner, 2003: 44).

Sejalan dengan hal tersebut, maka pembangunan merupakan tanggung jawab bersama antara pemerintah dan masyarakat. Dalam hal ini masyarakat menjadi sasaran sekaligus pelaku pembangunan. Keterlibatan masyarakat pada setiap tahapan pembangunan, merupakan salah satu kunci keberhasilan pembangunan. Kegagalan berbagai program pembangunan di masa lalu adalah disebabkan antara lain karena penyusunan, pelaksanaan dan evaluasi program-program pembangunan tidak melibatkan masyarakat.

Peran keterlibatan partisipasi juga penting karena pelembagaan sebagai sebuah strategi dilakukan justru untuk menghindari dominasi keputusan masyarakat oleh elit lokal, gagalnya pemberian ruang bagi kaum marginal, serta 
menghindari bias partisipasi. Dominasi keputusan masyarakat oleh elit dapat menyebabkan adanya perilaku mengambil untung secara berlebihan dan menggagalkan relasi timbal balik antara pemilik dengan wakilnya dalam mekanisme pendelegasian. Kegagalan pemberian ruang bagi kaum marginal menyebabkan partisipasi semu dan buruknya kolektifitas sebagai awal dari komitmen sosial. Pemberian ruang bagi kaum marginal adalah tahapan pengkapasitasan dan pendayaan bagi lapisan masyarakat yang terisolir secara sosial, ekonomi, dan geografi.

Tiga kendala yang dihadapi pemerintah untuk melibatkan masyarakat dalam kebijakan pembangunan yaitu; (I) instrumen hukum tidak mengatur secara eksplisit bagaimana, dimana dan siapa yang dilibatkan dalam pengambilan keputusan publik: (2) banyak LSM-LSM dan organisasi kemasyarakatan yang bergerak di berbagai bidang memiliki keterbatasan dalam membawa aspirasi rakyat; (3) banyaknya organisasi kemasyarakatan dan LSM di era reformasi menyulitkan untuk menentukan organisasi kemasyarakatan mana yang dapat dianggap mewakili aspirasi masyarakat.

Jalan keluar yang dapat dilakukan untuk mengatasi kendala partisipasi agar pelibatan masyarakat dalam pengambilan keputusan publik dapat berjalan baik adalah: (I) diperlukan instrument hukum yang secara subtantif mengatur pelibatan masyarakat, sehingga mekanisme pelibatan masyarakat menjadi jelas; (2) perlu keterbukaan dan akuntabilitas dari pihak pemerintah yang peka terhadap kepentingan publik; dan (3) masyarakat perlu bersatu dalam suatu wadah yang terorgasisir dan independent yang dapat digunakan sebagai saluran partisipasi.

Partisipasi (Keterlibatan) Masyarakat: (I) Ikut menentukan arah, strategi dan kebijakan pembangunan yang dilakukan pemerintah; (2) Ikut memikul beban dan bertanggung jawab dalam pelaksanaan pembangunan; (3) lkut memetik hasil dan manfaat pembangunan secara berkeadilan; (4) Partisipasi publik dalam kebijakan pembangunan di negara-negara yang menerapkan demokrasi termasuk di Indonesia bukanlah hal yang baru.

\section{METODE PENELITIAN}

Penelitian ini menggunakan teknik analisis data kuantitatif yang diharapkan dapat menggambarkan dan menjelaskan indikator variable penelitian dengan menggunakan "regresi linear berganda" dengan bantuan program microsta SPSS, juga menggunakan teknik analisis data tabel frekuensi untuk data kualitatif dengan menggunakan "Skala Litker" yang akan dideskripsikan secara kuantitatif.

Untuk mengumpulkan data yang diperlukan, maka penelitian ini menggunakan teknik pengumpulan data sebagai berikut:

I. Kuesioner

Kuesioner ditujukan kepada responden untuk mendapatkan data primer yang terkait dengan variabel penelitian, yaitu partisipasi masyarakat terhadap perencanaan pembangunan.

2. Wawancara

Wawancara langsung (interview) yaitu teknik yang digunakan untuk mendapatkan informasi dari informan yang berkaitan dengan variabel penelitian dengan menggunakan pedoman wawancara (interview guide).

3. Observasi

Observasi dalam penelitian ini adalah dimaksudkan sebagai teknik pengumpulan data untuk menjaring data pada saat kejadian itu berlangsung.

4. Dokumentasi

Teknik dokumentasi pada penelitian ini yaitu teknik mengumpulkan data melalui dokumen yang berkaitan dengan variabel penelitian sebagai sumber data baik dalam bentuk dokumen surat keputusan, literatur ilmiah, Koran, buleting, jurnal dan arsip.

\section{HASIL DAN PEMBAHASAN}

Sejalan dengan pemaparan diatas, dalam pelaksanaan pembagunan yang direncanakan oleh pemerintah partisipasi masyarakat merupakan hal yang sangat mempengaruhi keberhasilan proses pembangunan itu sendiri. Karena masyarakatlah yang mengetahui secara obyektif kebutuhan 
mereka. Partisipasi sebagai salah satu elemen pembangunan merupakan proses adaptasi masyarakat terhadap perubahan yang sedang berjalan. Dengan demikian partisipasi mempunyai posisi yang penting dalam pembangunan. Sumodingrat menambahkan, bahwa prasyarat yang harus terdapat dalam proses pembangunan berkelanjutan adalah dengan mengikutsertakan semua anggota masyarakat/rakyat dalam setiap tahap pembangunan (Sumodingrat, 2000: 88).

Conyers (dalam Mubiyarto, 2002: 19) memberikan tiga alasan utama sangat pentingnya partisipasi masyarakat dalam pembangunan, yaitu: (I) Partisipasi masyarakat merupakan suatu alat guna memperoleh informasi mengenai kondisi, kebutuhan dan sikap masyarakat setempat, yang tanpa kehadirannya program pembangunan dan proyek akan gagal, (2) Masyarakat mempercayai program pembagunan jika dilibatkan dalam proses persiapan dan perencanaannya, karena masyarakat lebih mengetahui seluk beluk proyek dan merasa memiliki proyek tersebut, (3) Partisipasi merupakan hak demokrasi masyarakat dalam keterlibatannya di pembangunan.

\section{Partisipasi pada Tahap Perencanaan}

Sehubungan dengan hal partisipasi masyarakat diatas, maka peneliti melihat sajauhmana keterlibatan masyarakat dalam mengambil peran dalam proses perencanaan pelaksanaan pembangunan pada berbagai tingkatan. Pada tingkatan desa sebagai organisasi terkecil dalam suatu masyarakat dapat penulis gambarkan sebagai berikut:

Tabel. I.I

Keterlibatan Masyarakat Dalam Pelaksanann Musrenbang Tingkat Desa

\begin{tabular}{|l|l|l|l|c|l|}
\hline No & Jawaban Responden & Skor & Frek. & F Skor & (\%) \\
\hline I. & Sangat terlibat & 5 & 0 & 0 & 0 \\
2. & Cukup terlibat & 4 & 0 & 0 & 0 \\
3. & Terlibat & 3 & 39 & 108 & 79,60 \\
4. & Kurang terlibat & 2 & 10 & 20 & 20,40 \\
5. & Sangat tidak terlibat & 1 & 0 & 0 & 0 \\
& & & & & \\
\hline & Jumlah & & 49 & 128 & 100,00 \\
\hline
\end{tabular}

Sumber: Hasil olahan data primer, 2016.

Tabel I.I: mengungkapkan bahwa pelaksanaan Musrenbang tingkat Desa dan Kelurahan melibatkan masyarakat dari berbagai golongan, hal ini dibuktikan oleh jawaban responden yang paling banyak pada klasifikasi "terlibat" dengan $79,60 \%$, dan pada klasfikasi "kurang terlibat" dengan 20,40\%. Keterlibatan masyarakat dalam Musrenbang karena disebabkan oleh himbauan dan undangan Kepala Desa agar supaya masyarakat dari berbagai golongan supaya menghadiri Musrembang.

Sejalan dengan hal tersebut, Menurut Peters (dalam Mubyarto, 2005: 90), partisipasi dapat tumbuh subur pada tata pemerintahan yang lebih menekankan keterlibatan masyarakat dalam proses pengambilan kebijakan dibanding hirarki dan teknokrasi. Kebijakan bukan persoalan teknis yang dapat diselesaikan secara teknokrasi oleh sekelompok orang yang dipercaya untuk merumuskannya, tetapi kebijakan merupakan ruang bagi teknokrat dan masyarakat untuk melakukan kerjasama dan menggabungkan pengetahuan. Oleh karena itu dalam menetapkan kebijakan harus melibatkan pihak yang luas dan menjamin kepentingan stakeholders.

Mengapa pelibatan masyarakat dalam perencanaan kebijakan pembangunan penting dilakukan, karena pelibatan masyarakat dalam membuat kebijakan merupakan faktor utama dalam good governance yang memberikan 
manfaat besar terhadap kepentingan public, diantaranya meningkatkan kualitas kebijakan yang dibuat dan sebagai sumber bahan masukan terhadap pemerintah sebelum memutuskan kebijakan. Bagi pendukung partisipasi, keunggulan partisipasi adalah menjamin ketercapaian tujuan, menjamin keberlanjutan, menjamin terakomodasinya suara kelompok marjinal terutama kelompok miskin dan perempuan. Bagi pengkritik model partisipasi berpendapat bahwa partisipasi dapat menyebabkan pembengkakan biaya dan waktu untuk formulasi kebijakan.

Oleh karena itu partisipasi merupakan keterlibatan mental dan emosi dari seseorang di dalam situasi kelompok yang mendorong mereka untuk menyokong kepada pencapaian tujuan pada tujuan kelompok tersebut dan ikut bertanggung jawab terhadap kelompoknya.(Siti Irene, 20II: 50) Dalam Peraturan Menteri Dalam Negeri Nomor 5 Tahun 2007 menyebutkan bahwa partisipasi adalah keikutsertaan dan keterlibatan masyarakat secara aktif dalam proses perencanaan pembangunan. Partisipasi adalah penentuan sikap dan keterlibatan hasrat setiap individu dalam situasi dan kondisi organisasinya, sehingga pada akhirnya mendorong individu tersebut untuk berperan serta dalam pencapaian tujuan organisasi, serta ambil bagian dalam setiap pertanggungjawaban bersama. (Ibnu Kencana, 2002: 132)

Partisipasi masyarakat atau partisipasi warga adalah proses ketika warga, sebagai makhluk individu maupun kelompok sosial dan organisasi, mengambil peran serta ikut mempengaruhi proses perencanaan pelaksanaan dan pemantauan kebijakan yang langsung mempengaruhi kehidupan mereka. (Sumarto, 2003:17) Menurut Pasaribu dan Simanjuntak, partisipasi masyarakat berarti masyarakat ikut serta, yaitu mengikuti dan menyertai pemerintah karena kenyataaannya pemerintahlah yang sampai dewasa ini merupakan perancang, penyelenggara, dan pembayar utama dalam pembangunan.masyarakat diharapkan dapat ikut serta, karena di seleggarakan dan dibiayai utama oleh pemerintah itu dimaksudkan untuk sebesarbesarnya kesejahteraan masyarakat sendiri, untuk rakyat banyak. (dalam Siti Fatimah, 2012:10)

Gordon W. Allport berpendapat bahwa seseorang yang berpartisipasi sebenarnya mengalami keterlibatan dirinya/egonya yang sifatnya lebih daripada keterlibatan dalam pekerjaan atau tugas saja, yang berarti keterlibatan pikiran dan perasaannya. Sedangkan Keith davis mengatakan bahwa partisipasi adalah keterlibatan mental pikiran dan emosi/perasaan seseorang di dalam situasi kelompok yang mendorongnya untuk memberikan sumbangan kepada kelompok dalam usaha mencapai tujuan serta turut bertanggung jawab terhadap usaha yang bersangkutan. Selain itu Alastaire White, mengemukan bahwa partisipasi adalah keterlibatan komunitas setempat secara aktif dalam pengambilan keputusan atau pelaksanaannya terhadap proyek-proyek pembangunan untuk masyarakat.(dalam Sunarti, 2003: 76).

Tabel 1.2

Keterlibatan Masyarakat dalam Konteks Identifikasi Program Pada Musrenbang Tingkat Desa

\begin{tabular}{|l|l|l|l|c|l|}
\hline No. & Jawaban Responden & Skor & Frek. & F Skor & $(\%)$ \\
\hline I. & Sangat terlibat & 5 & 0 & 0 & 0 \\
2. & Cukup terlibat & 4 & 0 & 0 & 0 \\
3. & Terlibat & 3 & 10 & 30 & 20,40 \\
4. & Kurang terlibat & 2 & 39 & 78 & 79,60 \\
5. & Sangat tidak terlibat & 1 & 0 & 0 & 0 \\
\hline & Jumlah & & 49 & 108 & 100,00 \\
\hline
\end{tabular}

Sumber: Hasil olahan data primer, 2016. 
Tabel I.2, mengungkapkan bahwa pelaksanaan Musrenbang tingkat Desa dan Kelurahan melibatkan masyarakat dari berbagai golongan, hal ini dibuktikan oleh jawaban responden yang paling banyak pada klasifikasi "terlibat" dengan 20,40\%, dan pada klasfikasi "kurang terlibat" dengan $79,60 \%$. Rendahnya keterlibatan masyarakat dalam pada tahapan identifikasi program pada saat Musrenbang disebabkan oleh masyarakat cenderung menganut sistem perwakilan ketokohan yang akan mengusulkan program/kegiatan yang di usulkan oleh masyarakat.

Keterlibatan masyarakat dalam rangka mengidentifikasi program pembangunan yang dibutuhkan oleh masyarakat sangat diperlukan karena identifikasi adalah kegiatan menentukan atau menetapkan identitas (ciri-ciri atau keadaan khusus) seseorang atau benda. Kegiatan identifikasi merupakan kegiatan awal dan merupakan kegiatan awal dan merupakan salah satu tujuan dari asesmen; dengan telah dilakukan identifikasi tersebut maka asesmen sudah mulai dilaksanakan, asesmen selanjutnya akan lebih dipermudah karena sudah ada data identitas seseorang yang akan diasesmen lebih lanjut. Identifikasi merupakan kegiatan menelaah atau mencari, menemukan, mengumpulkan, data dan informasi dari "kebutuhan" lapangan. Secara intensitas kebutuhan dapat dikategorikan (dua) macam yakni kebutuhan terasa yang sifatnya mendesak dan kebutuhan terduga yang sifatnya tidak mendesak.

Fungsi dan tujuan identifikasi kebutuhan program untuk mengetahui berbagai masalah atau kebutuhan program yang diinginkan masyarakat. Untuk mengetahui berbagai sumber yang dapat dimanfaatkan untuk pendukung pelaksanaan program dan mempermudah dalam menyusun rencana program yang akan dilaksanakan. Fungsi agar program yang dikembangkan sesuai dengan kebutuhan masyarakat. Data yang dikumpulkan dapat digunakan sebagai dasar penyusunan rencana program yang dapat di pengaruhi pengelola program. Sebagai bahan informasi bagi pihak lain yang membutuhkan
Strategi program pembangunan muncul sebagai alternatif dalam penyusunan rencana pembangunan menggantikan model perencanaan lama (konvensional), yaitu perencanaan jangka panjang (long-range planning) maupun perencanaan yang berbasis pada tujuan. Kebutuhan sebuah perencanaan strategis disebabkan perubahan eksternal yang terjadi dengan cepat dan tidak menentu. Hal ini menuntut sebuah organisasi atau komunitas untuk melakukan adaptasi terhadap perubahan itu secara internal agar mampu mempertahankan fungsi dan peranannya dalam memberikan pelayanan terbaik kepada kelompok sasaran. Oleh karena itu, organisasi harus mampu mengatasi lingkungan eksternal dan secara berkelanjutan melakukan kajian terhadap kapasitas internal sebagai prasyarat untuk tetap memelihara dan mempertahankan eksistensinya.

Identifikasi program pada penerapan model perencanaan konvensional berangkat dari asumsi penetapan tujuan jangka panjang sebagai entry point dalam pengelolaan sumber daya untuk mencapai tujuan yang telah ditetapkan. Sementara dalam perencanaan strategis berangkat dari visi, misi dan nilai-nilai yang menjadi dasar untuk merespon perubahan di masa depan. Dengan demikian perencanaan strategis merupakan bagian dari perubahan itu sendiri. Proses ini dilakukan melalui kajian sistematis yang memadukan visi, misi, serta perkembangan lingkungan eksternal berupa peluang dan ancaman serta kekuatan dan kelemahan sebagai lingkungan internal suatu organisasi untuk menentukan arah yang ingin dicapai. 
Tabel I.3

Keterlibatan Masyarakat Dalam Konteks Perumusan Program Mengklasifikasikan Program/Kegiatan Pada Musrenbang Desa

\begin{tabular}{|l|l|l|l|c|l|}
\hline No & Jawaban Responden & Skor & Frek. & F dan Skor & $(\%)$ \\
\hline I. & Sangat teribat & 5 & 0 & 0 & 0 \\
2. & Cukup terlibat & 4 & 0 & 0 & 0 \\
3. & Terlibat & 3 & 10 & 30 & 20,40 \\
4. & Kurang terlibat & 2 & 39 & 78 & 79,60 \\
5. & Sangat tidak terlibat & I & 0 & 0 & 0 \\
\hline & Jumlah & & 49 & 108 & 100,00 \\
\hline
\end{tabular}

Sumber: Hasil olahan data primer, 2016.

Tabel I.3 mengungkapkan bahwa keterlibatan masyarakat dalam konteks perumusan program dalam Musrenbang tingkat Desa dan Kelurahan hanya diikuti oleh sebagian kecil masyarakat yaitu pada klasifikasi "terlibat" dengan 20,40\%, dan pada klasfikasi "kurang terlibat" dengan 79,60\%. Pada tahapan pengklasifikasian program, keterlibatan masyarakat kurang disebabkan oleh karena pada tahapan ini aparat Desa/Kelurahan dan Kecamatan yang berkompeten untuk mengklasifikasikannya kemudian diusulkan ke pada SKPD masing-masing sesuai dengan urusan dan tufoksi SKPD tersebut, sebagai contoh untuk urusan Infrastruktur di usulkan ke Dinas PU, Jalan Tani diusukan ke Dinas Pertanian, urusan kesehatan ke Dinas Kesehatan dan seterusnya.

Dalam hal ini, proses penyusunan program harus dapat menjabarkan inisiatif menjadi beberapa program yang akan dilaksanakan beberapa tahun yang akan datang, memperkirakan investasi yang diperlukan untuk setiap program, menghitung perkiraan penerimaan yang dapat diperoleh dan menghitung perkiraan laba yang akan diperoleh. Penyusunan anggaran bertujuan untuk menentukan kegiatan tahun berikutnya dan sumber daya yang diperlukan. Anggaran disusun berdasarkan iniatif yang telah dirumuskan. Anggaran yang baik adalah: merupakan rencana tindakan terperinci, merupakan rencana satu-dua tahunan, menguraikan biaya yang diperlukan, mengidentifikasi pencapaian terpenting kegiatan tersebut, menyebutkan siapa yang akan bertanggung jawab, sebagai referensi menyusun rencana kinerja individual, ditulis secara singkat namun lengkap, alat untuk memantau kinerja dan diperbarui apabila terjadi perubahan-perubahan.

Beberapa asumsi yang dipakai untuk mendorong partisipasi masyarakat dalam rangka penyusunan sebuah peogram, yaitu :(I) Rakyatlah yang paling tahu kebutuhannya, karena rakyat mempunyai hak untuk mengidentifikasikan dan menentukan kebutuhan pembangunan di lokalnya; (2) Partisipasi sosial dapat menjamin kepentingan dan suara-suara kelompok yang selama ini dimarjinalkan dalam berbagai aspek pembangunan; (3) Partisipasi sosial dalam pengawasan terhadap proses pembangunan dapat menjamin tidak terjadinya berbagai penyimpangan, penurunan kualitas dan kuantitas pembangunan. Partisipasi masyarakat menekankan pada partisipasi langsung warga dalam pengambilan keputusan pada lembaga dan proses kepemerintahan.

Oleh karena itu partisipasi masyarakat dapat terjadi pada empat jenjang yaitu: (I) partisipasi dalam pengambilan keputusan; (2) partisipasi dalam pelaksanaan; partisipasi dalam pemanfaatan; dan (4) partisipasi dalam evaluasi. Partisipasi dalam proses pembuatan keputusan. Setiap proses penyelenggaraan, terutama dalam kehidupan bersama masyarakat, pasti melewati tahap penentuan kebijaksanaan. Partisipasi masyarakat pada tahap ini sangat mendasar sekali, terutama karena yang di ambil menyangkut 
nasib mereka secara keseluruhan yang menyangkut kepentingan bersama. Partisipasi dalam hal pengambilan keputusan ini bermacammacam, seperti kehadiran rapat, diskusi, sumbangan pemikiran, tanggapan atau penolakan terhadap program yang ditawarkan.

Partisipasi dalam perumusan program merupakan lanjutan dari rencana yang telah disepakati sebelumnya. Dalam hal ini Uphoff menegaskan bahwa partisipasi dalam pembangunan ini dapat dilakukan melalui keikutsertaan masyarakat dalam memberikan konstribusi guna menunjang pelaksanaan pembangunan yang berwujud tenaga, uang, barang, material, maupun informasi yang berguna bagi pelaksanaan pembangunan. Partisipasi dalam pengambilan manfaat. Partisipasi ini tidak terlepas dari kualitas maupun kuantitas dari hasil pelaksanaan program yang bisa dicapai. Dari segi kualitas, keberhasilan suatu program akan ditandai dengan adanya peningkatan output, sedangkan dari segi kuantitas dapat dilihat seberapa besar persentase keberhasilan program.

Tabel I.4

Keterlibatan Masyarakat Dalam Konteks Penyusunan Program Pada Musrenbang Tingkat Desa

\begin{tabular}{|l|l|l|l|c|l|}
\hline No & Jawaban Responden & Skor & Frek. & F Skor & $(\%)$ \\
\hline I. & Sangat teribat & 5 & 0 & 0 & 0 \\
2. & Cukup terlibat & 4 & 0 & 0 & 0 \\
3. & Terlibat & 3 & 9 & 27 & 18,37 \\
4. & Kurang terlibat & 2 & 40 & 80 & 81,63 \\
5. & Sangat tidak terlibat & 1 & 0 & 0 & 0 \\
\hline \multicolumn{5}{|c|}{ Sumber: Hasil olahan data primer, 2016. } \\
\hline
\end{tabular}

Tabel 1.4; mengungkapkan bahwa pelaksanaan Musrenbang tingkat Desa dan Kelurahan, khususnya dalam konteks penyusunan program kurang melibatkan masyarakat hal ini dibuktikan dengan jawaban responden yaitu pada klasifikasi "terlibat" dengan 18,37\%, dan pada klasfikasi "kurang terlibat" dengan 81,93\%. Kurangnya masyarakat yang terlibat dalam penyusunan program dikarenakan keterbatas pengetahuan masyarakat tentang masalahmasalah program pembangunan yang menjadi prioritas di desanya.

Disadari bahwa, penyusunan program adalah proses penentuan kegiatan-kegiatan yang akan dilaksanakan oleh suatu organisasi dalam jangka panjang (umumnya untuk jangka waktu 3-5 tahun), dan penaksiran jumlah sumber-sumber (resources) yang akan dialokasikan pada setiap program. Program umumnya disusun sesuai dengan jenis atau keluarga produk (product lines). Program sering pula disebut dengan perencanaan jangka panjang (long-range planning). Dalam penyusunan program terdapat tiga kegiatan pokok, yaitu : (I) Peninjauan kembali terhadap program yang sedang dilaksanakan oleh pemerintah rusahaan sangat diperlukan; (2) Mempertimbangkan usulan program baru. Dalam hal ini manajemen dihadapkan pada masalah pemilihan alternatif, yaitu : menerima atau menolak usulan program baru; (3) Mengkoordinasi program-program dalam suatu sistem penyusunan program secara formal : Sistem penyusunan program secara formal diperlukan oleh setiap organisasi, baik dalam kegiatan peninjauan kembali program-program yang sedang dilaksanakan maupun dalam pengambilan keputusan atas program baru.

Proses penyusunan program umumnya dimulai beberapa bulan menjelang dimulainya proses penyusunan anggaran. Penyusunan program yang formal umumnya melalui tahaptahap sebagai berikut: (I) Penentuan tujuan dan strategi dasar oleh manajemen puncak, yang hasilnya disebarkan kepada para manajer operasi; 
(2) Berpedoman pada tujuan dan strategi yang telah ditetapkan, para manajer operasi membuat usulan-usulan program untuk didiskusikan dengan manajemen puncak; (3) Usulan program tersebut didiskusikan oleh manajemen puncak dan para manajer operasi, jika perlu diadakan revisi, penambahan atau pengurangan, sehingga ditetapkan sebagai suatu program perusahaan secara keseluruhan.

Penyusunan program adalah proses pembuatan keputusan mengenai programprogram yang akan dilaksanakan oleh suatu organisasi dan taksiran jumlah sumber-sumber yang akan dialokasikan untuk setiap program tersebut. Program adalah kegiatan pokok yang akan dilaksanakan oleh suatu organisasi untuk melaksanakan strategi yang telah ditetapkan dalam perencanaan strategik.

Kegiatan Pokok Penyusunan Program. Untuk perusahaan yang sudah berjalan dan sudah memiliki program yang sedang berjalan, urutan ketiga macam kegiatan pokok penyusunan program tersebut meliputi: (I) Penelaahan program yang sedang berjalan; (2) Penyusunan dan analisis usulan program baru dan pembuatan keputusan atas usulan program tersebut; (3) Sistem pengkoordinasian program yang terpisah sehíngga dapat mengoptimalkan fungsi perusahaan sebagai suatu kesatuan.

\section{Pada Tahap Pelaksanaan}

Partisipasi masyarakat di dalam setiap proses pembuatan kebijakan publik merupakan hal penting sebagai cermin asas demokrasi di suatu negara. Hal ini menjadi sangat tepat ketika partisipasi masyarakat kemudian diangkat menjadi salah satu prinsip yang harus dijalankan oleh pemerintah dalam upaya mewujudkan good governance (kepemerintahan yang baik). Prinsip partisipasi dalam upaya mewujudkan good governance yang dilakukan melalui pembangunan infrastruktur jalan sangat sejalan dengan pandangan baru yang berkembang di dalam partisipasi masyarakat dengan cara melihat masyarakat tidak hanya sebagai penonton melainkan sebagai masyarakat yang memiliki jiwa membantu dan mau bekerja sama dalam pembanguan yang ada di dalamnya (owner).

Pembangunan desa mempunyai makna membangun masyarakat perdesaan dengan mengutamakan pada aspek kebutuhan masyarakat (Adisasmita, 2006:4). Pelaksanaan pembangunan yang mengutamakan masyarakat dalam pelaksanaan program-program pembangunan, berarti memberikan peluang seluas-luasnya kepada masyarakat untuk mengarahkan sumber daya, potensi, merencanakan serta membuat keputusan dan mengevaluasi kegiatan-kegiatan pembangunan yang akan mensejahterakan mereka, sehingga mereka berdaya. Partisipasi masyarakat dalam pembangunan merupakan keterlibatan anggota masyarakat dalam pembangunan, meliputi kegiatan dalam perencanaan dan pelaksanaan (implementasi) program atau proyek pembangunan yang dikerjakan di dalam masyarakat lokal.

Partisipasi atau peran serta masyarakat dalam pembangunan pedesaan dapat diartikan sebagai aktualisasi dari kesediaan dan kemampuan anggota masyarakat untuk berkorban dan berkontribusi dalam implementasi program atau proyek di masyarakat (Adisasmita, 2006:34). Salah satu tujuan kegiatan Program Pembangunan Infrastruktur Pedesaan (PPIP) adalah untuk meningkatkan peran serta masyarakat dalam membangun kesadaran dan kemandirian masyarakat dalam mengatasi permasalahannya dan penyediaan infrastruktur perdesaan. Dari 3 sasaran utama kegiatan Program Pembangunan Infrastruktur Pedesaan (PPIP) adalah : I) Tersedianya infrastruktur perdesaan yang sesuai dengan kebutuhan masyarakat, berkualitas, berkelanjutan, dan berwawasan lingkungan. 2) Meningkatnya kemampuan masyarakat pedesaan dalam penyelenggaraan infrastruktur perdesaan dan 3) Terlaksananya penyelenggaraan pembangunan infrastruktur perdesaan yang partisipatif, transparan, akuntabel, dan berkelanjutan. 
Tabel 2.I

Peran Aktif Masyarakat Dalam Konteks Pengawasan Pelaksanaan Program Pembangunan Pada Tingkat Desa

\begin{tabular}{|l|l|l|l|c|l|}
\hline No & Jawaban Responde & Skor & Frek. & F Skor & (\%) \\
\hline & & & & & \\
I. & Sangat Aktif & 5 & 0 & 0 & 0 \\
2. & Cukup aktif & 4 & 0 & 0 & 0 \\
3. & Aktif & 3 & 20 & 60 & 40,81 \\
4. & Kurang aktif & 2 & 29 & 58 & 59,19 \\
5. & Sangat tidak aktif & 1 & 0 & 0 & 0 \\
& & & & & \\
\hline & Jumlah & & 49 & 118 & 100,00 \\
\hline
\end{tabular}

Tabel 2.I mengungkapkan bahwa keterlibatan masyarakat dalam hal pengawasan terhadap program pembangunan yang ada didesanya berada pada klasifikasi "kurang aktif" dengan 59, 19\% dan pada klasifikasi “aktif” dengan $40,81 \%$. Data tersebut mengungkapkan bahwa kurang teribatnya masyarakat dalam melakukan pengawasan tersebut karena kehadiran program tersebut tidak sesuai dengan kebutuhan masyarakat sebagaimana yang diharapkan, sehingga masyarakat tidak peduli terhadap pelaksanaan program pembangunan tersebut.

Sejalan dengan pelaksanaan program pembangunan, dimana peran aktif masyarakat dalam pengawasan sangat dibutuhkan. Pengawasan merupakan rangkaian kegiatan yang harus dilakukan atau diadakan untuk penyempurnaan dan penilaian sehingga dapat mencapai tujuan seperti yang direncanakan. Sangat penting untuk mengetahui sampai di mana pekerjaan sudah dilaksanakan, mengevaluasi dan menentukan tindakan korektif atau tindak lanjut, sehingga pengembangan pekerjaan dapat ditingkatkan pelaksanaannya. Dengan demikian pengawasan merupakan segala usaha, kegiatan atau tindakan untuk mengetahui dan menilai pelaksanaan tugas atau kegiatan yang dilaksanakan berjalan sesuai dengan rencana yang telah ditetapkan.

Adanya suatu proses perbandingan antara rencana dan pelaksanaan, maka pengawasan dapat disebut sebagai bagian dari manajemen. $\mathrm{Hal}$ mana disebut demikian karena dalam proses manajemen yang lengkap dan sempurna dilakukannya fungsi-fungsi manajemen, antara lain menurut Terry sebagaimana dikutip Panglaikim dan Kansil (1960) dalam Supriatna (1997) yaitu meliputi empat fungsi manajemen masing-masing Planning, Organizing, Actuiting, and Controlling.

Nawawi (2003) menyatakan pengawasan masyarakat (social control) disingkat dalam bahasa Indonesia (Wasmas) adalah setiap pengaduan, kritik, saran, pertanyaan dan lain-lain yang disampaikan anggota masyarakat mengenai pelaksanaan pekerjaan oleh unit organisasi kerja non profit di bidang pemerintahan dalam melaksanakan tugas pokoknya memberikan pelayanan umum (public service) dan pembangunan untuk kepentingan kehidupan bermasyarakat, berbangsa dan bernegara.

$$
\text { Zainum (2004) menyatakan }
$$

masyarakatpun melakukan pengawasan terhadap manajemen sumber daya manusia berupa pengawasan masyarakat (Wasmas) yang dapat dilakukan melalui media massa, termasuk surat pembaca, melalui kotak pos 5000, melalui surat ke instansi masing-masing, melalui petisi atau resolusi melalui demonstrasi, melalui lembaga perwakilan, melalui delegasi dan melalui pengaduan ke Pengadilan Umum dan/atau pengadilan Tata Usaha Negara yang secara khusus menampung pengaduan masyarakat bila mana terdapat tindakan melanggar hukum dari pejabat maupun pegawai pemerintah. 
Secara teknis, pengawasan dimuat dalam Keputusan Presiden Republik Indonesia Nomor 74 Tahun 200I tentang Tata Cara Pengawasan Penyelenggaraan Pemerintah Daerah, pasal 9 ayat (I) menyatakan masyarakat dapat melakukan pengawasan terhadap penyelenggaraan Pemerintahan Daerah Provinsi dan Pemerintahan Daerah Kabupaten/Kota; pasal (2) Pengawasan sebagaimana dimaksud pada ayat (I) dilakukan secara perorangan, kelompok maupun organisasi masyarakat.

Secara nyata dapat dikatakan bahwa pengawasan masyarakat (social control) dapat diartikan sebagai pengawasan yang dilakukan oleh warga masyarakat baik perorangan maupun kelompok, baik secara lisan atau tertulis yang ditujukan kepada organ pemerintah yang berkompoten dalam melaksanakan pelayanan umum (public service) dalam bentuk pikiran, ide/gagasan, maupun keluhan pengaduan yang bersifat positif atau membangun secara langsung maupun melalui medium/sarana lain (media massa).

Dalam pelaksanaan pengawasan masyarakat (social control) tidak terlepas dari norma umum pengawasan sehingga tujuannya tidak berorientasi subyektivitas akan tetapi berorientasi obyektivitas. Pengawasan masyarakat (social control) yang dilakukan masyarakat di desa penelitian, ditujukan kepada pemerintah desa (Kepala Desa dan perangkatnya) sebagai suatu reaksi yang timbul akibat kinerja pemerintah desa yang tidak maksimal dalam pelaksanaa kegiatan pembangunan secara umum. Dari beberapa permasalahan yang terjadi, bermula dari kebijakan-kebijakan yang dilaksanakan pemerintah desa yang tidak melibatkan atau mengikutsertakan warga dalam pengambilan keputusan.

Tabel 2.2

Peran Aktif Masyarakat Dalam Konteks Koordinasi Pelaksanann Program Pembangunan Pada Tingkat Desa

\begin{tabular}{|c|c|c|c|c|c|}
\hline No & Jawaban Responden & Skor & Frek. & F. Skor & $(\%)$ \\
\hline I. & Sangat aktif & 5 & 0 & 0 & 0 \\
\hline 2. & Cukup aktif & 4 & 0 & 0 & 0 \\
\hline 3. & Aktif & 3 & II & 33 & 22,44 \\
\hline 4. & Kurang aktif & 2 & 48 & 96 & 77,56 \\
\hline 5. & Sangat tidak aktif & I & 0 & 0 & 0 \\
\hline & Jumlah & & 49 & 129 & 100,00 \\
\hline
\end{tabular}

Tabel 2.2; mengungkapkan bahwa dalam pelaksanaan program pembangunan pada tingkat desa terlihat aktivitas masyarakat dalam hal ini yang diwakili oleh BPD dan lembaga masyarakat lainnya kurang terlibat dalam kegiatan koordinasi dalam hal lebih mengefektifkan pelaksananan program pembangunan yang ada didesanya. $\mathrm{Hal}$ ini dikarenakan oleh kurang terbukanya pemerintah desa yaitu aparat yang terbitkan dalam kegiatan program pembangunan untuk berkoordinasi dengan masyarakat. Kondisi tersebut dibuktikan oleh jawaban responden yang paling banyak pada klasifikasi "kurang aktif" dengan $77,56 \%$, dan pada klasfikasi "terlibat" dengan $22,44 \%$.

Dalam pelaksanaan sebuah program pembangunan, khususnya yang ada didesa, maka peran masyarakat dalam bentuk koordinasi dengan pemerintah desa sangat diperlukan sebagai instrument pengawasan. Koordinasi adalah kegiatan yang dilakukan oleh berbagai pihak yang sederajat untuk saling memberikan informasi dan bersama mengatur atau menyepakati sesuatu, sehingga di satu sisi proses 
pelaksanaan tugas dan keberhasilan pihak yang satu tidak mengganggu proses pelaksanaan tugas dan keberhasilan pihak yang lainnya. Sementara pada sisi lain yang satu langsung atau tidak langsung mendukung pihak yang lain. Menurut James G March dan Herben A Simon, bahwa Koordinasi adalah suatu proses untuk mencapai kesatuan tindakan di antara kegiatan yang saling bergantungan.

Koordinasi menurut Terry, adalah suatu sinkronisasi yang tertib dalam upaya untuk memberikan jumlah yang tepat, waktu dan mengarahkan pelaksanaan yang mengakibatkan harmonis dan tindakan terpadu untuk tujuan lain. Pandangan mengenai koordinasi ini menarik perbedaan antara koordinasi dengan kerja sama. Kerja sama diartikan sebagai aksi kolektif satu orang dengan yang lain atau orang lain menuju tujuan bersama.

Jika dilihat dari sudut normatifnya, maka koordianasi diartikan sebagai kewenangan untuk menggerakkan, menyelaraskan, menyerasikan dan menyeimbangkan kegiatan-kegiatan yang spesifik atau berbeda, agar nantinya semua terarah pada pencapaian tujuan tertentu pada waktu yang telah ditetapkan. Dari sudut fungsionalnya, koordinasi dilakukan guna mengurangi dampak negatif spesialisasi dan mengefektifkan pembagian kerja.

Adapun tujuan koordinasi, yaitu: (I) untuk menciptakan dan memelihara efektivitas organisasi setinggi mungkin melalui sinkronisasi, penyerasian, kebersamaan dan keseimbangan antara berbagai kegiatan dependen suatu organisasi; (2) untuk mencegah konflik dan menciptakan efisiensi setinggi-tingginya di setiap kegiatan interdependen yang berbeda-beda melalui kesepakatan yang mengikat semua pihak yang bersangkutan; (3) untuk menciptakan dan memelihara iklim dan sikap saling responsifantisipatif di kalangan unit kerja interdependen dan independen yang berbeda-beda, agar keberhasilan unit kerja yang satu tidak dirusak oleh keberhasilan unit kerja yang lainnya, melalui jaringan informasi dan komunikasi efektif.

Dengan demikian, koordinasi memiliki syarat-syarat yakni : (I) Sense of Cooperation, perasaan untuk saling bekerja sama, dilihat per bagian; (2) Rivalry, dalam organisasi besar, sering diadakan persaingan antar bagian, agar saling berlomba; (3) Team Spirit, satu sama lain per bagian harus saling menghargai; (4) Esprit de Corps, bagian yang saling menghargai akan makin bersemangat. Selanjutnya koordinasi memiliki sifat-sifat sebagai berikut : (I) Koordinasi adalah dinamis, bukan statis; (2) Koordinasi menekankan pandangan menyeluruh oleh seorang manajer dalam kerangka mencapai sasaran; (3) Koordinasi hanya meninjau suatu pekerjaan secara keseluruhan.

Koordinasi merupakan tindakan seorang pimpinan untuk mengusahakan terjadinya keselarasan, antara tugas dan pekerjaan yang dilakukan oleh seseorang atau bagian yang satu dengan bagian yang lain. Dengan koordinasi ini diartikan sebagai suatu usaha ke arah keselarasan kerja antara anggota organisasi sehingga tidak terjadi kesimpang siuran, tumpang tindih. Hal ini berarti pekerjaan akan dapat dilaksanakan secara efektif dan efisien.

Jadi dapat disimpulkan bahwa koordinasi merupakan proses pengintegrasian tujuan dan aktivitas di dalam suatu perusahaan atau organisasi agar mempunyai keselarasan di dalam mencapai tujuan yang ditetapkan, pengkoordinasian dimaksudkan agar para manajer mengkoordinir sumber daya manusia dan sumber daya lain yang dimiliki organisasi tersebut. Kekuatan suatu organisasi tergantung pada kemampuannya untuk menyusun berbagai sumber dayanya dalam mencapai suatu tujuan.

Hasibuan (2006:88), berpendapat bahwa faktor-faktor yang mempengaruhi koordinasi sebagai berikut: (a) Kesatuan Tindakan, Pada hakekatnya koordinasi memerlukan kesadaran setiap anggota organisasi atau satuan organisasi untuk saling menyesuaikan diri atau tugasnya dengan anggota atau satuan organisasi lainnya agar anggota atau satuan organisasi tersebut tidak berjalan sendiri-sendiri. Oleh sebab itu konsep kesatuan tindakan adalah inti dari pada koordinasi; (b) Komunikasi, tidak dapat dipisahkan dari koordinasi, karena komunikasi, sejumlah unit dalam organisasi akan dapat dikoordinasikan berdasarkan rentang dimana sebagian besar ditentukan oleh adanya 
komunikasi. Komunikasi merupakan salah satu dari sekian banyak kebutuhan manusia dalam menjalani hidup dan kehidupannya. Sehingga dari uraian tersebut terlihat fungsi komunikasi sebagai berikut : (a). Mengumpulkan dan menyebarkan informasi mengenai kejadian dalam suatu lingkungan; (b) Menginterpretasikan terhadap informasi mengenai lingkungan; (c) Kegiatan mengkomunikasikan informasi, nilai dan norma sosial dari generasi yang satu ke generasi yang lain.

Tabel 2.3

Peran Aktif Masyarakat Dalam Konteks Swadaya Program Pembangunan pada tingkat Desa

\begin{tabular}{|l|l|l|l|c|l|}
\hline No & Jawaban Responden & Skor & Frek. & F Skor & $(\%)$ \\
\hline I. & Sangat teribat & 5 & 0 & 0 & 0 \\
2. & Cukup terlibat & 4 & 0 & 0 & 0 \\
3. & Terlibat & 3 & 25 & 75 & 51,02 \\
4. & Kurang terlibat & 2 & 24 & 48 & 48.98 \\
5. & Sangat tidak terlibat & 1 & 0 & 0 & 0 \\
\hline \multicolumn{5}{|r|}{ Sumber: Hasil olahan data primer, 2016. } \\
\hline \multicolumn{6}{|c|}{ Jumlah } \\
\hline
\end{tabular}

Tabel 2.3: mengungkapkan bahwa salah satu bentuk keterlibatan masyarakat dalam pemanfaatan hasil pembangunan adalah adanya swadaya masyarakat dalam pelaksanaan pembangunan, khususnya di Desa dan Kelurahan yang melibatkan masyarakat dari berbagai lapisan. Data tersebut menunjukkan bahwa masyarakat belum sepenuhnya menyadari kegiatan swadaya masyarakat, hal ini dibuktikan dengan jawaban responden yang paling banyak pada klasifikasi "terlibat" dengan 5I,02\%, dan pada klasfikasi "kurang terlibat" dengan 48,98\%.

Peran Swadaya Masyarakat dalam pemanfaatan hasil-hasil pembangunan, hususnya terlihat dalam aktivtas membangun infrastruktur (sarana prasarana) dengan mendapatkan bantuan dari pemerintah tanpa memperhatikan peran dan partisipasi masyarakat. Hal ini peran masyarakat dan partisipasinya cukup dibutuhkan dalam penyelesaian sarana dan prasarana yang dibangun di Desa yang mendapatkan bantuan. Manun perlu disadari kesadaran akan swadaya masih cukup rendah, dimana masyarakat hanya mengharapkan bantuan itu diperoleh kemudian dikerajakan ala kadarnya bahwa ini bantuan Pemerintah untuk rakyat. Padahal pembangunan itu akan dirasakan dan dinikmati oleh mereka secara keseluruhan.

Target minimal pemberdayaan adalah membangun perubahan pola pikir masyarakat.
Dari menengadahkan tangan menjadi menelungkupkan tangan bukan hanya menerima namun juga memiliki. Sebenarnya masyarakat sejak dulu memiliki kesadaran itu namun menjadi berubah, apakah kerena akibat kemiskinan struktural, ya kemiskinan struktural karena, selama ini berhadapan dengan pemerintahan yang kurang trasparan, sehingga mereka ragu dalam mengulurkan sumbangannya pada pembangunan terutama yang melibatkan pemerintah.

$\mathrm{Hal}$ inilah membangun kesadaran yang secara transparan bahwa membangunan itu adalah dari rakyat oleh rakyat dan untuk rakyat. Setelah banyak kita rasakan hasil pekerjaan prasarana yang melibatkan masyarakat dapat terukur kesadaran swadaya baik uang, material maupun tenaga adalah dari kualitas, volume atau kuantitas cukup dapat dirasakan dan terukur secara pasti. Pembangunan yang terencana dengan baik, administrasi yang jujur dan transaparan, serta hasilnya berkualitas pasti akan memunculkan kesadaran untuk berswadaya, bahkan di masa datang akan melahirkan kemandirian, didukung dengan peningkatan ekonomi dan kualitas hidup mereka. Misalkan pembangunan rabat beton atau sender irigasi mereka akan meraskan tebal, tinggi dan panjang yang tercapai, serta kualitas bangunan baik beton maupun sender. Dimana keawetannya, ketebalan, 
kekerasannya akan berbeda antara yang tinggi swadayanya dengan rendah swadayanya.

\section{Partisipasi Pada Tahap Pemanfaatan Hasil Pembangunan}

Partisipasi dalam menikmati hasil dapat dilihat dari tiga segi, yaitu dari aspek manfaat materialnya, manfaat sosialnya dan manfaat pribadi. Sedangkan partisipasi dalam evaluasi ini berkaitan dengan masalah pelaksanaan program secara menyeluruh. Partisipasi ini bertujuan untuk mengetahui apakah pelaksanaan program telah sesuai dengan yang ditetapkan atau ada penyimpangan. (Josef Riwu, 2007:127).

Masyarakat memegang kendali atas pemanfaatan hasil-hasil pembangunan dan partisipasi masyarakat juga berarti adanya keterlibatan langsung bagi warga dalam proses pengambilan keputusan dan kontrol serta koordinasi dalam mempertahankan hak-hak sosialnya. Jika dikaitkan dengan tingkat kekuasaan yang diberikan kepada masyarakat dikaitkan dengan partisipasi sebagaimana dijelaskan oleh Shery Arstein, maka peran serta masyarakat dalam perencanaan dapat dibedakan ke dalam anak tangga sebagai berikut : (a) Citizen power Pada tahap ini terjadi pembagian hak, tanggung jawab, dan wewenang antara masyarakat dan pemerintah dalam pengambilan keputusan. Tingkatan meliputi kontrol masyarakat, pelimpahan, dan kemitraan. (b) Tokenism Pada tahap ini hanya sekedar formalitas yang memungkinkan masyarakat mendengar dan memiliki hak untuk member suara, tetapi pendapat mereka belum menjadi bahan dalam pengambilan keputusan. Tingkatan meliputi penetraman, konsultasi, dan informasi; (c) Non partipation Pada tahap ini masyarakat hanya menjadi objek. Tingkatan ini meliputi terapi dan manipulasi. Berdasarkan anak tangga dapat diasumsikan bahwa partisipasi yang mampu menggerakkan dinamika masyarakat adalah partisipasi yang diklasifikasikan ke dalam citizen power, karena dalam konteks inilah terdapat ketelibatan masyarakat sipil sebagai pilar penting dalam menggerakkan masyarakat demokratis.

Secara khusus lagi peter Oakley mencoba memetakan partisipasi dalam tujuh tingkatan sebagaimana dijelaskan sebagai berikut : (a) Manipulation Tingkat paling rendah mendekati situasi tidak ada partisipasi, cenderung berbentuk indotrinasi; (b) consultation Stakeholder mempunyai peluang untuk memberikan saran akan digunakan seperti yang mereka harapkan; (c) Consensus building Pada tingkat ini stakeholder berinteraksi untuk saling memahami dan dalam posisi saling bernegosiasi, toleransi dengan seluruh anggota kelompok; (d) Decision-making Consensus terjadi disarkan pada keputusan kolektif dan bersumber pada rasa tanggung jawab untuk menghasilkan sesuatu; (e) Risk-taking Proses yang berlangsung dan berkembang tidak hanya sekedar menghasilkan keputusan, tetapi memikirkan akibat dari hasil yang menyangkut keuntungan, hambatan, dan impikasi.

Tabel 3.I

Peran Masyarakat Dalam Konteks Rasa Memiliki Hasil Pembangunan Pada Tingkat Desa

\begin{tabular}{|c|c|c|c|c|c|}
\hline No & Jawaban Responden & Skor & Frek. & F. Skor & (\%) \\
\hline $\mathrm{I}$. & Sangat merasa memiliki & 5 & 0 & 0 & 0 \\
\hline 2. & Cukup merasa memiliki & 4 & 0 & 0 & 0 \\
\hline 3. & Memiliki & 3 & 10 & 30 & 20,40 \\
\hline 4. & Kurang memiliki & 2 & 39 & 78 & 79,60 \\
\hline 5. & Sangat tidak memiliki & 1 & 0 & 0 & 0 \\
\hline & Jumlah & & 49 & 108 & 100,00 \\
\hline
\end{tabular}


Tabel 3.I; mengungkapkan bahwa penyelesaian program pembangunan yang ada di desa dan Kelurahan terkesan tidak sesuai dengan harapan dan kebutuhan masyarakat sebagaimana yang dirumuskan dan ditetapkan dalam Musrenbang tingkat Desa dan kelurahan, sehingga kurang memotivasi masyarakat untuk merasa memiliki hasil pembangunan tersebut. Kondisi masyarakat seperti ini dibuktikan oleh jawaban responden yang paling banyak pada klasifikasi "kurang merasa memiliki" dengan $79,60 \%$, dan pada klasfikasi "merasa memiliki” dengan $20,40 \%$.

Rasa memiliki (sense of belonging) merupakan ekspresi jiwa yang penting dalam kehidupan seseorang. Rasa memiliki juga akan memiliki dampak yang nyata terlihat secara signifikan di dalam perilaku seseorang. Seseorang yang memiliki rasa memiliki akan bertindak peduli, terikat, memiliki empati, termotivasi bahkan mampu memberdayakan dirinya sendiri meskipun tidak ada stimulan. Contoh konkret rasa memiliki di dalam kehidupan adalah ketika seseorang merasa memiliki rumah, maka dia akan senantiasa menjaga dan membersihkan rumah tersebut terlebih rumah tersebut adalah tempat bernaungnya. Ketika seseorang memiliki anak, maka dia akan berupaya memberikan yang terbaik bagi anak-anaknya. Bahkan ketika seseorang memelihara binatang peliharaan seperti burung ataupun kucing, dia akan menjaga agar binatang peliharaannya tidak mati kelaparan dan dapat selalu sehat.

Rasa memiliki ini cenderung tidak terlihat di dalam dunia kerja. Cukup banyak dari kita yang memandang pekerjaan sebagai beban dan tempat bekerja hanya sebagai pihak yang memasok gaji untuk melangsungkan kehidupan kita. Ironisnya rasa memiliki ini hampir luntur (bahasa halus dari nyaris tidak ada) di dalam perusahaan. Kita seringkali menyepelekan hal-hal kecil yang jika digabung secara keseluruhan berpotensi merugikan perusahaan tempat kita bekerja dan mencari nafkah ini.

Acapkali kita melakukan pemborosan yang tidak disengaja yang terjadi karena sikap ketidakpedulian yang merupakan buah dari tidak adanya rasa memiliki. Contoh rasa tidak memiliki, yaitu: Lupa mematikan air di kamar kecil, lupa mematikan pendingin udara ketika tidak ada orang bahkan lupa menutup valve secara rapat, lupa memeriksa apakah suku cadang yang digunakan untuk sarana produksi masih ada atau tidak dan yang lebih parah adalah lupa melayani pelanggan dengan baik serta tidak jujur dengan menyembunyikan fakta akan berdampak sangat besar bagi perusahaan tempat kita mencari nafkah.

Oleh sebab itu sudah sepatutnya kita peduli dan mengembangkan rasa memiliki terhadap terhadap sesuatu yang menjadi sumber kehidupan kita. Sumber kehidupan yang digarap dengan rasa syukur, rasa memiliki dan rasa cinta akan memberikan hasil yang memadai bagi penggarapnya, demikian pula dengan pekerjaan yang dilakukan dengan kerelaan dan rasa cinta. Singkatnya sikap memiliki terhadap hasil pembangunan akan memberikan hasil yang positif bagi kelangsungan kehidupan kita.

Tabel 3.2

Peran Masyarakat Dalam Konteks Pemeliharaan Hasil Pembangunan Tingkat Desa

\begin{tabular}{|c|c|c|c|c|c|}
\hline No & Jawaban Responden & Skor & Frek. & F. Skor & (\%) \\
\hline \multirow{6}{*}{$\begin{array}{l}\text { I. } \\
2 . \\
3 . \\
4 . \\
5 .\end{array}$} & Sangat memelihara & 5 & 0 & 0 & 0 \\
\hline & Cukup memelihara & 4 & 0 & 0 & \\
\hline & Memelihara & 3 & 10 & 30 & 20,40 \\
\hline & Kurang memelihara & 2 & 39 & 78 & 79,60 \\
\hline & Sangat tidak memelihara & I & 0 & 0 & 0 \\
\hline & Jumlah & & 49 & 108 & 100,00 \\
\hline
\end{tabular}


Tabel 3.2 mengungkapkan bahwa hasil-hasil pembangunan yang telah ada di desa dan kelurahan terlihat kurang dipelihara oleh masyarakat secara swadaya karena keterbatasan dana dan kurang rasa memiliki atas hasil pembangunan yang ada. Oleh karena itu ada beberapa hasil pembangunan yang tidak terpelihara dengan baik. Dalam hal ini pemerintah desa juga tidak menyiapkan anggaran untuk pemeliharaan infrastruktur pembangunan tersebut. Hal ini dibuktikan oleh jawaban responden yang paling banyak pada klasifikasi "kurang memelihara" dengan 79,60\%, dan pada klasfikasi "memelihara” dengan 20,40\%.

Pemeliharaan (maintenance) adalah kombinasi dari berbagai kegiatan yang dilakukan untuk memelihara fasilitas Produksi termasuk mesin dan alat-alat produksi lainnya atau untuk memperbaikinya sampai pada suatu kondisi yang dapat diterima. Selain itu pemeliharaan juga dapat diartikan sebagai suatu kegiatan menjaga fasilitasfasilitas dan peralatan pabrik serta mengadakan perbaikan atau penyesuaian yang diperlukan agar tercapai suatu keadaan operasi produksi yang memuaskan dan sesuai dengan yang direncanakan.

Aktifitas pemeliharaan (maintenance) sangat diperlukan karena: (I) Setiap peralatan mempunyai umur penggunaan (useful life).suatu saat dapat mengalami kegagalan/kerusakan; (2) Kita tidak dapat mengetahui dengan tepat kapan peralatan akan mengalami kerusakan (failure); dan (3) Manusia selalu berusaha untuk meningkatkan umur penggunaan dengan melakukan perawatan. Pemeliharaan (maintenance) berperang penting dalam kegiatan produksi dari suatu perusahaan yang menyangkut kelancaran atau kemacetan produksi, volume produksi, serta agar produk dapat diproduksi dan diterima konsumen tepat pada waktunya (tidak terlambat) dan menjaga agar tidak terdapat sumber daya kerja (mesin dan karyawan) yang menganggur karena kerusakan (downtime) pada mesin sewaktu proses produksi sehingga dapat meminimalkan biaya kehilangan produksi atau bila mungkin biaya tersebut dapat dihilangkan.
Dengan demikian, pemeliharaan memiliki fungsi yang sama pentingnya dengan fungsi-fungsi lain dari suatu perusahaan. Karena pentingnya aktivitas pemeliharaan maka diperlukan perencanaan yang matang untuk menjalankannya, sehingga terhentinya proses produksi akibat rusak dapat dikurangi seminimum mungkin. Pemeliharaan yang baik akan mengakibatkan kinerja perusahaan meningkat, kebutuhan konsumen dapat terpengaruhi tepat waktu, serta nilai investasi yang dialokasikan untuk peralatan dan mesin dapat diminimalkan. Selain itu pemeliharaan yang baik juga dapat meningkatkan kualitas produk yang dihasilkan dan mengurangi waste yang berarti mengurangi ongkos produksi.

Pelaksanaan dari perawatan ini memerlukan beberapa hal penting, yaitu diantaranya: (I) Orang yang berwenang atau bertanggung jawab terhadap pelaksanaan; (2) Perencanaan dan penjadwalan perawatan; (3) Pengawasan untuk dapat menjaga agar tujuan perawatan dapat terpenuhi; (4) Diperlukan pula penyesuaian bila terjadi suatu penyimpangan, perubahan terhadap kinerja produksi.

\section{KESIMPULAN}

Berdasarkan hasil analisis pengaruh partisipasi masyarakat terhadap perencanaan pembangunan pada Badan Perencanaan Pembangunan Daerah Kabupaten Enrekang, maka dapat disimpulkan sebagai berikut:

I. Pembangunan partisipatif secara sederhana dapat diartikan sebagai pembangunan yang mengacu pada kebutuhan masyarakat, direncanakan dan dilaksanakan oleh masyarakat dengan sebesar-besarnya memamfaatkan potensi sumber daya (alam, manusia, kelembagaan, nilai-nilai sosial budaya) yang ada dan dapat diakses oleh masyarakat setempat. Karena itu pembangunan partisipatif merupakan pembangunan yang berangkat dari perencanaan yang dirumuskan oleh masyarakat sendiri sebagai obyek dan subyek pembangunan; 
2. Partisipasi merupakan keiukutsertaan seseorang atau sekelompok anggota masyarakat dalam suatu kegiatan pembangunan. Partisipasi masyarakat dapat dilihat pada tiga hal yaitu: Partisipasi pada tahap perencanaan pembangunan, partisipasi pada saat pelaksanaan pembangunan dan partisipasi pada saat pemamfaatan hasil pembangunan, berdasarkan (I) hasil analisis deskriptif menunjukkan bahwa partisipasi masyarakat berpangaruh secara siginifikan terhadap perencanan pembangunan, yaitu: variabel Perencanan (XI) dengan $80,11 \%$; dan variabel Pelaksanaan (X2) dengan $62,60 \%$; dan variabel pemanfaatan hasil pembangunan (X3) dengan $79,60 \%$; dan (2) hasil analisis statistic, yaitu pengaruh variabel $X$ secara simultan terhadap $Y$ pada kategori "sangat nyata" pada taraf $5 \%$ (t hit 4, I5 > t tab 2,60) dan $1 \%$ (t hit $4.15>$ tab 2,9l).

3. Keterhubungan antara variabel partisipasi masyarakat dengan variabel perencanaan pembangunan pada klasifikasi "berpengaruh", namun dalam hal ini tidak terlepas dati beberapa factor yang ikut mempengaruhi partispasi masyarakat dalam perencanaan pembangunan, yaitu sebagai factor penghambat: (a) factor kemauan; (b) factor kesempatan; dan (c) factor kemampuan. Kondisi ini di Desa dan Kelurahan pada umumnya memiliki komptensi dan keterampilan yang berkaitan dengan tahapantahapan Musrembang.

4. Dampak dari hasil perencanaan pembangunan yang menunjukkan adanya ketidaksesuain antara harapan dan kebutuhan masyarakat pada tingkat desa dan kelurahan, sehingga masyarakat memiliki sikap yang kurang merespon hasil pembangunan yang ada. Pernyataan sikap tersebut, terlihat pada: (I) pelembagaan nilai-nilai partipasi sebagai sebuah sendi demokrasi belum menjadi prioritas masyarakat; (2) peran aktif masyarakat, khususnya dalam konteks Musrembang tingkat Desa dan Kelurahan belum terwujud sesuai dengan harapan pemerintah, karena belum dipahaminya makna sebenarnya tentang partisipasi oleh pihak perencana dan pelaksana pembangunan (3). Banyaknya peraturan yang meredan keinginan masyarakat untuk berpastisipasi.

\section{DAFTAR PUSTAKA}

[1] Abipradja, Soedjono. 200I. Perencanaan Pembangunan di Indonesia. Surabaya Airlangga University Press.

[2] Achmad Mansyur, 2010. Teori-Teori Mutakhir Administrasi Publik. Yogyakarta, Rangkang Edication.

[3] Ahmad Jamaluddin, 2015. Metode Penelitian Administrasi Publik (Teori dan Aplikasi), Yokyakarta, Gava Media.

[4] Bryant dan White. 2000. Manajemen Pembangunan: Untuk Negara Berkembang. LP3ES. Jakarta

[5] Burhan Bunging, 2009. Metode Penelitian Kuantitatif, Yogyakarta: UGM Press.

[6] Handoko, T. hani. 2008. Manajemen Edisi 2. Yogyakarta: BPFE

[7] Hamaru, Usman. 2010. Strategi Pengembangan Koordinasi Perencanaan Terpadu Bappeda Provinsi Gorongtalo. UNM. Makassar,

[8] Holil Soelaiman. 2000. Partisipasi Sosial dalam Usaha Kesejahteraan Sosial. Bandung,

[9] Ibrahim, H. Amin. 2008. Pokok-Pokok Administrasi Publik dan Implementasinya. Bandung: Refika Aditama

[10] Isbandi Rukminto, 2007. Perencanaan Partisipatoris Berbasis Aset Komunitas: dari Pemikiran Menuju Penerapan. Depok: FISIP UI Press.

[II] Keban, Jeremias, T. 2008. Dimensi-Dimensi Strategik Administrasi Publik: Konsep, Teori, dan Isu. Yogyakarta. Gaya Media.

[12] Kunaryo. 2004. Perencanaan dan Pembiayaan Pembangunan. Jakarta: UI PRESS.

[13] Mardikantoro, 2003. Partisipasi Masysrakat dan Perencanaan Pembangunan. Yogyakarta: UGM Press,

[14] Osborne, David. Ted Gaebler. 2002. Meriusahakan Birokrasi Reiventing Government. Terjemahan oleh Abdul Rosyid 1999. Jakarta: Teruna grafica.

[15] Ratam, Waluyo, 200I. "Peranan Birokrasi Dalam Pembangunan" Makalah Disampaikan pada Diskusi Panel Persada Makassar

[16] Riyadi, Deddy Supriadi Bratakusuma. 2005. Perencanaan Pembangunan Daerah. Jakarta: gramedia Pustaka Utama. 
[17] Rizal, Suryadi. 200I. Perencanaan Pembangunan. Jakarta: Pusat Penerbitan Universitas Terbuka.

[18] Rokhman, Ali. 2005; Visi Publik, Jurnal Ilmu Administrasi Publik. Jurusan Ilmu Administrasi Negara Fakultas Ilmu Sosial dan Imu politik, Universitas Jenderal Soedirman, Purwokerto.

[19] Stoner, James. A,F. Charles Wankel. 2003. Perencanaan dan Pengambilan Keputusan Dalam Manajemen (I) Terjemahan oleh Sahat Simamora, 1993. Jakarta: Renika Cipta.

[20] Silvia Bolgherini 2010, "Participation" dalam Mauro Calise and Theodore J. Lowi, Hyperpolitics: An Interactive Dictionary of Political Science.

[2I] Semardayanti, 200I. Manajemen Sumber Daya Manusia. Jakarta: Hajimasagung.

[22] Tjokroamidjojo. Bintoro. 2004. Perencanaan Pembangunan. Jakrta: Hajimasagung.

[23] Tjokrowinoto, 200I. Manajemen Pembangunan. Jakarta : PT Raja Grafindo Persada 